\title{
Thrips collected in watermelon crops in the semiarid of Rio Grande do Norte, Brazil
}

\author{
Tripes coletados na cultura da melancia no semiárido do Rio Grande do Norte, Brasil
}

\author{
Ewerton Marinho Costa ${ }^{I^{*}}$ Maria Goretti Araújo de Lima ${ }^{I I}$ Rui Sales Junior \\ Adriano Cavalleri' ${ }^{\mathrm{III}}$ Elton Lucio Araujo
}

- NOTE -

ABSTRACT

The aim of this research was to report the occurrence of two species of thrips in watermelon crops in the semiarid region of Rio Grande do Norte, Brazil. From August to September 2011, we performed weekly sampling of thrips in a commercial watermelon production area with 10,000 ${ }^{2}$, using 20 Moericke traps. We captured a total of 431 thrips, belonging to Frankliniella schultzei (Trybom) (Thripidae) and Haplothrips gowdeyi (Franklin) (Phlaeothripidae). This is the first report of $\boldsymbol{H}$. gowdeyi in watermelon crops in Brazil.

Key words: Citrullus lanatus, Thysanoptera, Frankliniella schultzei, Haplothrips gowdeyi.

\section{RESUMO}

$O$ objetivo deste trabalho foi relatar a ocorrência de duas espécies de tripes na cultura da melancia na região do semiárido do Rio Grande do Norte, Brasil. Durante os meses de agosto e setembro de 2011 foram realizadas coletas de tripes semanalmente, em uma área de produção comercial de melancia de $10.000 \mathrm{~m}^{2}$, utilizando-se 20 armadilhas Moericke. Foram capturados um total de 431 tripes, pertencente às espécies Frankliniella schultzei (Trybom) (Thripidae) e Haplothrips gowdeyi (Franklin) (Phlaeothripidae). Este é o primeiro relato de ocorrência destas espécies no semiárido do Rio Grande do Norte e o primeiro registro de $\boldsymbol{H}$. gowdeyi na cultura da melancia no Brasil.

Palavras-chave: Citrullus lanatus, Thysanoptera, Frankliniella schultzei, Haplothrips gowdeyi.

The cultivation of watermelon (Citrullus

lanatus) (Cucurbitaceae) is one of the main segments of agribusiness in the semiarid region of Rio Grande do Norte (RN), the third largest producer of watermelon in the Northeastern Region of Brazil (IBGE, 2013). Small, medium and large producers, with production for the domestic and foreign markets, practice the cultivation of this cucurbit in $\mathrm{RN}$ (GRANGEIRO et al., 2005).

In Brazil, the attack of insect pests is one of the major threats that can limit the production of watermelon, frequently causing losses to producers. Some thrips (Insecta: Thysanoptera) as Thrips tabaci Lindeman, 1889, Thrips palmi Karny, 1925 and Frankliniella schultzei (Trybom, 1910) are reported causing damage to flowers and leaves of watermelon plants (MONTEIRO et al., 1999; MICHEREFF FILHO et al., 2010). However, there are scarce surveys on the diversity of thrips associated with watermelon crops, especially in the major production areas in the Northeast Brazil. Considering these aspects, the aim of this study was to report the occurrence of species of thrips collected in watermelon crop in the semiarid region of $\mathrm{RN}$.

The sampling was carried out from August to September 2011, in a commercial watermelon production area with $10,000 \mathrm{~m}^{2}(50 \mathrm{~m}$ width X $200 \mathrm{~m}$ long), cultivated with Crimson Sweet variety, in the Baraúna county $\left(05^{\circ} 05^{\prime} 55,6^{\prime \prime} \mathrm{S}\right.$ e $\left.37^{\circ} 41^{\prime} 20,8^{\prime \prime} \mathrm{W}\right)$, Rio Grande do Norte, Brazil. During the sampling, the cultural practices of maintenance (fertilization,

\footnotetext{
'Departamento de Ciências Vegetais, Universidade Federal Rural do Semi-Árido (UFERSA), Km 47, BR 110, 59625-900, Mossoró, RN, Brasil. E-mail: ewertonmarinho10@hotmail.com. *Corresponding author.

IIDepartamento de Biologia, Universidade Estadual do Ceará (UECE), Fortaleza, CE, Brasil.

IIIDepartamento de Zoologia, Universidade Federal do Rio Grande do Sul (UFRGS), Porto Alegre, RS, Brasil. Received 10.06.13 Approved 01.27.14 Returned by the author 11.17.14 CR-2013-1322.R1
} 
weeding and watering) and spraying of pesticides were performed (Thiophanate methyl and metalaxyl + mancozeb at 15 and 35 days after planting - DAP). The study area was surrounded by bands of preserved native vegetation (Caatinga) $(10 \mathrm{~m}$ distant from the edge of the area). The average monthly temperatures were $26.4^{\circ} \mathrm{C}$ in August and $27.6^{\circ} \mathrm{C}$ in September; and the relative humidity was: $63.3 \%$ in August and $54.4 \%$ in September (Source: Climatological Station Jerônimo Rosado - UFERSA, Mossoró, RN, 2011).

Sampling of thrips was performed weekly during the crop cycle (approximately 60 days in the study site), using 20 Moericke traps $(15 \mathrm{~cm}$ diameter and $7 \mathrm{~cm}$ height), containing a mix of water $(400 \mathrm{~mL})$ and mild detergent $(2 \%)$, distributed parallel to the planting lines, in two lines (central) of the cultivation ( $6 \mathrm{~m}$ distant from each other), where each row contained 10 traps spaced $16 \mathrm{~m}$. The traps were installed one week after sowing, placed on the soil and alongside the planting line, and remained in the area until the harvest, allowing seven samplings. After each weekly sampling, the mix of water and mild detergent within the traps was renewed.

The thrips captured in the traps were collected with the help of a thin brush and packed in plastic containers, properly labeled (date and place of collection), containing AGA (1:1:10 parts of glycerin, glacial acetic acid and ethyl alcohol $60 \%$, respectively). Then, they were sent to the Laboratory of Ecology of the Universidade Estadual do Ceará (UECE), mounted on microscope slides and identified according MOUND \& MARULLO (1996) and MOUND \& KIBBY (1998). The specimens are deposited in the zoological collection of the Laboratory of Ecology of UECE, Department of Biology.

A total of 431 thrips were collected, being 425 F. schultzei (422 yellow form and 3 dark form) and 6 Haplothrips gowdeyi (Franklin, 1908). F. schultzei is a polyphagous species, probably originated from South America (HODDLE et al., 2012). It is currently widely distributed throughout the world and reported in all regions of Brazil, including the state of $\mathrm{RN}$ (MONTEIRO et al., 2001; CAVALLERI \& MOUND, 2012). In Brazil, the species is considered a pest of cotton (Gossypium hirsutum) (Malvaceae), melon (Cucumis melo) (Cucurbitaceae), mango (Mangifera indica) (Anacardiaceae), lettuce (Lactuca sativa) (Asteraceae), tomato (Solanum lycopersicun) (Solanaceae), pepper (Capsicum annuum) (Solanaceae), tobacco (Nicotiana tabacum) (Solanaceae), eggplant (Solanum melongena) (Solanaceae), soybean (Glycine max) (Fabaceae), rose (Rosa sp.) (Rosaceae) and watermelon (C. lanatus) (Cucurbitaceae) (MONTEIRO et al., 1999; MONTEIRO et al., 2001; BARBOSA et al., 2005; MESQUITA et al., 2008; MICHEREFF FILHO et al., 2010; LIMA et al., 2013).

Frankliniella schultzei varies greatly on its morphology, and exhibits two different color morphs: a light and a dark form. These forms have similar distributions and often occur together in various parts of the world (HODDLE et al., 2012). The darker is usually predominant in plants grown in Brazil, including cucurbits (MONTEIRO et al., 1999). However, this contrasts with the high number of the light form found during this work.

Frankliniella schultzei is considered a pest of watermelon by attacking mainly its leaves (MONTEIRO et al., 1999; MONTEIRO et al., 2001). In addition to the direct feeding damages, $F$. schultzei can also be a vector of tospovirus (MONTEIRO et al., 2001; WHITFIELD et al., 2005; RILEY et al., 2011). It is important to mention that, although a pest in various crops, there is a report of $\boldsymbol{F}$. schultzei acting as facultative predator of mites (WILSON et al., 1996).

Haplothrips gowdeyi has a pantropical distribution, and feeds mainly on flowers (MOUND \& ZAPATER, 2003). In Brazil, H. gowdeyi was recorded on nectarine flowers (Prunus persica var. nuscipersica) (Rosaceae) in the states of Santa Catarina and Paraná (HICKEL \& DUCROQUET, 1998; SCHUBER et al., 2008), peach (P. persica) (Rosaceae) in Paraná and São Paulo (SCHUBER et al., 2008; PINENT et al., 2008), and recently in association with cowpea (Vigna unguiculata) (Fabaceae) in the state of Piauí (LIMA et al., 2013). This thrips is not a vector of tospovirus and so far, there are no reports of damage caused by this species. This is the first occurrence of $\boldsymbol{H}$. gowdeyi in watermelon crops in Brazil. Further field observations are needed to determine whether these plants serve as hosts of this species.

\section{ACKNOWLEDGMENTS}

To the Conselho Nacional de Desenvolvimento Científico e Tecnológico (CNPq) by granting master's scholarship to the first author. To Marcos R.D. Santos, Francisco S. Santos and Paolo A.F. Silva (undergraduate students in Agronomy / UFERSA) and Carlos H. F. Nogueira (postgraduate student in Plant Science / UFERSA), for the help in sampling.

\section{REFERENCES}

BARBOSA, F.R. et al. Artrópodes-praga e predadores (Arthropoda) associados à cultura da mangueira no Vale do São 
Francisco, Nordeste do Brasil. Neotropical Entomology, v.34, n.3, p.471-474, 2005. Available from: <http://www.scielo.br/ scielo.php?script $=$ sci_arttext\&pid $=\mathrm{S} 1519-566 \mathrm{X} 2005000300016>$. Accessed:Set. 10,2013. doi: 10.1590/S1519-566X2005000300016.

CAVALLERI, A.; MOUND, L.A. Toward the identification of Frankliniella species in Brazil (Thysanoptera, Thripidae). Zootaxa, v.3270, p.1-30, 2012. Available from: <http://www. mapress.com/zootaxa/list/2012/3270.html>. Accessed: Set. 05, 2013.

GRANGEIRO, L.C. et al. Acúmulo e exportação de nutrientes pela cultivar de melancia mickylee. Revista Caatinga, v.18, n.2, p.73-81, 2005. Available from: <http://www.redalyc.org/articulo. oa? id=237121137002>. Accessed: Jul. 10, 2013.

HICKEL, E.R.; DUCROQUET, J.P.H.J. Tripes associados à floração da nectarina em Santa Catarina. Anais da Sociedade Entomológica do Brasil, v.27, n.2, p.307-308, 1998. Available from: $<$ http://www.scielo.br/scielo.php?pid=S0301$80591998000200020 \&$ script $=$ sci arttext $>$. Accessed: Jun. 10, 2013. doi: $10.1590 / \mathrm{S} 0301-80591998000200020$.

HODDLE, M.S. et al. Thrips of California. Queensland: CBIT Publishing, 2012. Available from: <http://keys.lucidcentral. org/keys/v3/thrips_of_california/Thrips_of_California.html>. Accessed: Set. 04, 2013.

IBGE. Produção agrícola. Available from: $<\mathrm{http}: / /$ www.ibge. gov.br/home/>. Accessed: Ago. 27, 2013.

LIMA, E.F.B. et al. Thrips species (Insecta: Thysanoptera) associated to cowpea in Piauí, Brazil. Biota Neotropica, v.13, n.1, p.383-386, 2013. Available from: <http://www.scielo.br/ scielo.php?pid $=\mathrm{S} 1676-06032013000100043 \&$ script $=$ sci arttext $>$. Accessed: Set. 30,2013. doi: 10.1590/S1676-06032013000100043.

MESQUITA, A.L.M. et al. Efeito de inseticidas sobre o tripes Frankliniella schultzei (Trybom) em mangueira. Fortaleza: EMBRAPA, 2008. 4p. (Comunicado Técnico 134)

MICHEREFF FILHO, M. et al. Pragas da melancia e seu controle. Brasília: EMBRAPA Hortaliças, 2010. 18p. (Circular Técnica 92).

MONTEIRO, R.C. et al. Espécies de Frankliniella (Thysanoptera: Thripidae) de importância agrícola no Brasil. Neotropical Entomology, v.30, n.1, p.65-72, 2001. Available from: $\quad<\mathrm{http}: / /$ www.scielo.br/scielo.php?pid=S1519566X2001000100011\&script $=$ sci arttext $>$. Accessed: Jun. 05, 2013. doi: 10.1590/S1519-566X2001000100011.
MONTEIRO, R.C. et al. Thrips (Thysanoptera) as pest of plant production in Brazil. Revista Brasileira de Entomologia, v.43, p.163-171, 1999.

MOUND, L.A.; KIBBY, G. Thysanoptera: an identification guide. Wallingford: CABI, 1998. 70p.

MOUND, L.A.; MARULLO, R. The thrips of Central and South America: an introduction (Insecta: Thysanoptera). Florida: Memoirs on Entomology, International, 1996. 487p.

MOUND, L.A.; ZAPATER, M.C. South American Haplothrips species (Thysanoptera: Phlaeothripidae), with a new species of biological control interest to Australia against weedy Heliotropium amplexicaule (Boraginaceae). Neotropical Entomology, v.32, n.3, p.437-442, 2003. Available from: <http://www.scielo.br/ scielo.php?script $=$ sci arttext\&pid $=S 1519-566$ X20030003000 09\&lng=en\&nrm=iso\&tlng=en>. Accessed: Jul. 02, 2013. doi: 10.1590/S1519-566X2003000300009.

PINENT, S.M.J. et al. Thrips (Thysanoptera: Thripidae, Phlaeothripidae) damaging peach in Paranapanema, São Paulo state, Brazil. Neotropical Entomology, v.37, n.4, p.486-488, 2008. Available from: $\quad<$ http://www.scielo.br/scielo.php?script=sci arttext\&pid=S1519-566X2008000400019>. Accessed: Jul. 02, 2013. doi: 10.1590/S1519-566X2008000400019.

RILEY, D.G. et al. Thrips vectors of tospoviruses. Journal of Integrated Pest Management, v.1, n.2, p.1-10, 2011. Available from: <http://esa.publisher.ingentaconnect.com/content/esa/ jipm/2011/00000002/00000001/art00004>. Accessed: Set. 30, 2013. doi: 10.1603/IPM10020.

SCHUBER, J.M. et al. Thysanoptera coletados em pomares de Prunus persica no município de Araucária, Paraná. Scientia Agraria, v.9, n.3, p.411-414, 2008. Available from: <http://ojs. c3sl.ufpr.br/ojs-2.2.4/index.php/agraria/article/view/12507/8604> . Accessed: Jun. 01, 2013.

WHITFIELD, A.E. et al. Tospovirus-thrips interactions. Annual Review of Phytopatology, v.43, p.459-489, 2005. Available from: <http://www.annualreviews.org/ doi/full/10.1146/annurev.phyto.43.040204.140017?url ver=Z39.88-2003\&rfr_id=ori:rid:crossref.org\&rfr_dat $=\mathrm{cr}$ pub\%3dpubmed\&>. Accessed: Set. 02, 2013. doi: 10.1146/ annurev.phyto.43.040204.140017.

WILSON, L.J. et al. Phytophagous thrips are facultative predators of twospotted spider mites (Acari: Tetranychidae) on cotton in Australia. Bulletin of Entomological Research, v.86, n.3, p.297305, 1996. Available from: <http://journals.cambridge.org/action/ displayAbstract? fromPage $=$ online $\&$ aid $=2598164>. \quad$ Accessed: Set. 10, 2013. doi: 10.1017/S0007485300052597. 